Supporting Information for

$\mathrm{Yb}^{3+}, \mathbf{E r}^{3+}$ Co-doped Cerium Oxide Upconversion Nanoparticles Enhanced Enzyme-like Catalytic Activity and Anti-Oxidation for Potential Parkinson's

\title{
Disease Treatment
}

Yuemei $\mathrm{Li}^{*}$, Yongmei Li ${ }^{b}$, Haoming Wang ${ }^{c}$, Riyue Liu ${ }^{a}$

${ }^{a}$ Xiamen Cardiovascular Hospital, Xiamen University, No.2999 Jinshan Road, Huli District, Xiamen, Fujian 361012, China

${ }^{b}$ NHC Key Laboratory of Hormones and Development, Tianjin Key Laboratory of Metabolic Diseases, Chu Hsien-I Memorial Hospital \& Tianjin Institute of Endocrinology, Tianjin Medical University, No.6 Huanrui North Road, Ruijing Street, Beichen District, Tianjin, 300134, China.

${ }^{c}$ Department of Human Anatomy and Histology, Tianjin Medical University, Tianjin 300070, China

${ }^{*}$ This author is corresponding author.

Correspongdence author: Yuemei Li,E-mail:972491839@qq.com 


\section{Contents}

\section{Experiments}

Table S1. The ICP-AES results of $\mathrm{Yb} / \mathrm{Er} / \mathrm{CeO}_{2-\mathrm{x}}$ upconversion nanoparticles.

Figure S1. The X-ray diffraction of pure $\mathrm{CeO}_{2-\mathrm{x}}$ and $\mathrm{Yb} / \mathrm{Er} / \mathrm{CeO}_{2-\mathrm{x}}$ upconversion nanoparticles.

Figure S2. The UV/Vis absorption curves of $\mathrm{Yb} / \mathrm{Er} / \mathrm{CeO}_{2-\mathrm{x}}, \mathrm{Yb} / \mathrm{Er} / \mathrm{CeO}_{2-\mathrm{x}}$ with $\mathrm{H}_{2} \mathrm{O}_{2}$ and $\mathrm{Yb} / \mathrm{Er} / \mathrm{CeO}_{2-\mathrm{x}}$ with $\mathrm{H}_{2} \mathrm{O}_{2}$ after 24 hours.

Figure S3. Relative catalytic activity of $\mathrm{Yb} / \mathrm{Er} / \mathrm{CeO}_{2-\mathrm{x}}$ with different $\mathrm{Yb}^{3+}$ concentrations ( $0 \mathrm{~mol} \%, 1 \mathrm{~mol} \%, 3 \mathrm{~mol} \%, 5 \mathrm{~mol} \%, 7 \mathrm{~mol} \%$ and $9 \mathrm{~mol} \%$ ).

Figure S4. Scavenging activity of $\mathrm{H}_{2} \mathrm{O}_{2}$ by $\mathrm{Yb} / \mathrm{Er} / \mathrm{CeO}_{2-\mathrm{x}}$ with different $\mathrm{Yb}^{3+}$ concentrations ( $0 \mathrm{~mol} \%, 1 \mathrm{~mol} \%, 3 \mathrm{~mol} \%, 5 \mathrm{~mol} \%, 7 \mathrm{~mol} \%$ and $9 \mathrm{~mol} \%)$.

Figure S5. CAT-like activity of $\mathrm{Yb} / \mathrm{Er} / \mathrm{CeO}_{2-\mathrm{x}}$ with different $\mathrm{Yb}^{3+}$ doping concentrations.

Figure S6. GPx-like activity of $\mathrm{Yb} / \mathrm{Er} / \mathrm{CeO}_{2-\mathrm{x}}$ with different $\mathrm{Yb}^{3+}$ doping concentrations. 


\section{Experiments}

\section{Synthesis and characterization of $\mathrm{Yb} / \mathrm{Er} / \mathrm{CeO}_{2-\mathrm{x}}$ upconversion nanoparitlces}

$\mathrm{Ce}\left(\mathrm{NO}_{3}\right)_{3} \cdot 6 \mathrm{H}_{2} \mathrm{O}(99.9 \%), \mathrm{Er}\left(\mathrm{NO}_{3}\right)_{3} \cdot 5 \mathrm{H}_{2} \mathrm{O}, \mathrm{Yb}\left(\mathrm{NO}_{3}\right) \cdot 5 \mathrm{H}_{2} \mathrm{O}$ and $\mathrm{C}_{16} \mathrm{H}_{22} \mathrm{~N}_{2} \mathrm{O}_{4} \mathrm{~S}(\mathrm{TMB})$ were purchased from Macklin company. $\mathrm{C}_{6} \mathrm{H}_{5} \mathrm{Na}_{3} \mathrm{O}_{7}, \mathrm{NaOH}, \mathrm{NaAc}$ and $\mathrm{HAc}$ was obtained from Aladdin. Deionized water used for all experiments. Yb and Er co-doped $\mathrm{CeO}_{2-\mathrm{x}}$ was synthesized via the hydrothermal method. $\mathrm{Ce}\left(\mathrm{NO}_{3}\right)_{3} \cdot 6 \mathrm{H}_{2} \mathrm{O}$ was dissolved ( $5 \mathrm{mmol}$ ) in $15 \mathrm{~mL}$ deionized water, while was stirred $1 \mathrm{~h}$ at $25^{\circ} \mathrm{C}$. The addition of $\mathrm{NaOH}(4 \mathrm{~mol} / \mathrm{L})$ and $\mathrm{C}_{6} \mathrm{H}_{5} \mathrm{Na}_{3} \mathrm{O}_{7}(0.3 \mathrm{~g})$ in the $\mathrm{Ce}\left(\mathrm{NO}_{3}\right)_{3}$ solution and continue to stir $2 \mathrm{~h}$ at $25^{\circ} \mathrm{C} . \mathrm{Er}\left(\mathrm{NO}_{3}\right)_{3} \cdot 5 \mathrm{H}_{2} \mathrm{O}$ of $1 \mathrm{~mol} \%$ and $\mathrm{Yb}\left(\mathrm{NO}_{3}\right) \cdot 5 \mathrm{H}_{2} \mathrm{O}$ of $1 \sim 9 \mathrm{~mol} \%$ dropped into the previous mixture and stirred for $1 \mathrm{~h}$. The solution color changed from yellow to colorless. Afterwards, the solution transferred to a reaction kettle $(25 \mathrm{~mL})$ and reacted at $180{ }^{\circ} \mathrm{C}$ for $24 \mathrm{~h}$. The obtained samples in the reaction kettle cooled to room temperature. $\mathrm{Yb} / \mathrm{Er} / \mathrm{CeO}_{2-\mathrm{x}} \mathrm{UCNPs}$ centrifuged at $6000 \mathrm{rpm}$ for $10 \mathrm{~min}$ with each of ethanol and water for three times, respectively. The achieve samples was dried at $60{ }^{\circ} \mathrm{C}$ for $24 \mathrm{~h}$. SEM and TEM images were measured at $15 \mathrm{kV}$ using a focus voltage SU8000 SEM and $200 \mathrm{kV}$ using a focus voltage JEOL 2010F TEM, respectively. The X-ray diffraction of the $\mathrm{Yb} / \mathrm{Er} / \mathrm{CeO}_{2-\mathrm{x}}$ and $\mathrm{CeO}_{2-\mathrm{x}}$ were recorded by XRD-600 with speed of $10 \%$ min. UV-visible spectra were obtained by a UV spectrophotometer. XPS was conducted with a Physical Electronics 5000 Versa probe II at a power of $210 \mathrm{~W}$. The 
upconversion emission spectra of the nanoparticles were measured using $980 \mathrm{~nm}$ excitation. The decay lifetime of sample presented on a computer with $980 \mathrm{~nm}$ laser, MD03024 Mixed Domain Oscilloscope. Atomic emission spectrometer (ICP) was measured via NCS Testing Technology Company Limited.

\section{The enzyme-like catalytic activity of $\mathrm{Yb} / \mathrm{Er} / \mathrm{CeO}_{2-\mathrm{x}} \mathrm{UCNPs}$}

The NaAc-HAc buffer ( $5 \mathrm{~mL}, \mathrm{pH}=0.5,3.2 \mathrm{M}$ ) added the $\mathrm{Yb} / \mathrm{Er} / \mathrm{CeO}_{2-\mathrm{x}} \mathrm{UCNPs}(200$ $\mathrm{mg} / \mathrm{mL})$ with different $\mathrm{Yb}^{3+}$ concentrations $(0 \mathrm{~mol} \% \sim 9 \mathrm{~mol} \%)$, and put into a centrifuge. TMB of $50 \mu \mathrm{L}$ the ethanol solution $(25 \mathrm{mM})$ dropped into the mixed solution. The mixed solution put into the constant temperature culture oscillator at $35^{\circ} \mathrm{C}$ for 10 min. the upper blue solution was taken into the quartz cuvette by centrifuge and separate. Relative catalytic activity of $\mathrm{Yb} / \mathrm{Er} / \mathrm{CeO}_{2-\mathrm{x}}$ with different $\mathrm{Yb}^{3+}$ concentrations was measured via ultraviolet visible spectrophotometer. The standard curve of $\mathrm{H}_{2} \mathrm{O}_{2}$ was achieved. The catalase-like activity of $\mathrm{Yb} / \mathrm{Er} / \mathrm{CeO}_{2-\mathrm{x}}$ with $\mathrm{Yb}^{3+}$ concentration from 0 mol\% to $9 \mathrm{~mol} \%$ were obtained according to a commercial catalase assay kit (Abcam). CAT-like and GPx-like activities of $\mathrm{Yb} / \mathrm{Er} / \mathrm{CeO}_{2-\mathrm{x}}$ with $\mathrm{Yb}^{3+}$ concentrations from $0 \mathrm{~mol} \%$ to $9 \mathrm{~mol} \%$ were estimated using a CAT assay kit and GPx-like assay kit (Solarbio, Shanghai, China)

\section{Animal experiment.}

Healthy male C57 mice ( $8 \sim 10$ weeks old ) were purchased from animal center of the Military Medical Sciences Academy of the Peoples Liberation Army (Permission No. SCXK-(A) 2012-0004). Experimental animal house in Tianjin Medical University. Animals were maintained on a $12 \mathrm{~h}$ light $/ 12 \mathrm{~h}$ dark cycle at $22{ }^{\circ}$ Cand $55 \pm 5 \%$ relative 
humidity with food and water ad libitum. The mice was allowed to acclimatize for one week prior to experimentation. The mice was randomly divided into the following groups ( $\mathrm{n}=10$ per group): UCNPs-group injected $2 \mathrm{mg} / \mathrm{kg} \mathrm{Yb} / \mathrm{Er} / \mathrm{CeO}_{2-\mathrm{x}}$ via the tail vein. MPTP-induced acute Parkinson's disease mice were received MPTP (20mg/kg) intraperitoneally every 2 hours for four times per day (MPTP group). MPTP (1-methyl4-phenyl-1,2,3,6-tetrahydropyridine) was purchased Sigma-Aldrich, St.Louis, MO. UCNPs-treated group was injected UCNPs of $2 \mathrm{mg} / \mathrm{kg}$ via the tail. After $24 \mathrm{~h}$, the mice treated with MPTP (intraperitoneally $20 \mathrm{mg} / \mathrm{kg}$ ) every 2 hours for four times. $\mathrm{Yb} / \mathrm{Er} / \mathrm{CeO}_{2-\mathrm{x}}$ of $2 \mathrm{mg} / \mathrm{kg}$ was injected again via the tail vein after $24 \mathrm{~h}$. The control group treated with equivalent volume of phosphate-buffered solution (PBS). Mice from each group was sacrificed by $\mathrm{CO}_{2}$ asphyxiation after $24 \mathrm{~h}$. Substantia nigra and striatum tissue were collected and divided into three specimens. One specimen excised and stored at -20 degrees for oxidative stress detection. The other specimen was fixed for immune-histochemical staining and Immuno-fluorescent staining.

Histological Analysis. The brain tissues were fixed with 10\% formaldehyde for $48 \mathrm{~h}$, and then the tissues were embedded in paraffin. Sections of $5 \mu \mathrm{m}$ were stained for histological assessment. Antigen retrieval was achieved by sections in $10 \mathrm{mM}$ sodium citrate $(\mathrm{pH}=6.0)$ for $10 \mathrm{~min}$ at $98{ }^{\circ} \mathrm{C}$. The sections were incubated in $3 \% \mathrm{H}_{2} \mathrm{O}_{2}$ for blocking endogenous peroxidase activity. Blocking was received in 5\% BSA for $1 \mathrm{~h}$ at room temperature. For immunohistochemical analysis, the sections were incubated with antibody against tyrosine hydroxylase (TH, 1:400, Cell Signaling Technology, USA), $\alpha$-Synuclein ( $\alpha$-syn,1:300, Cell Signaling Technology, USA) at $4{ }^{\circ} \mathrm{C}$ overnight, 
and then an HRP labeled polymer secondary antibody for $0.5 \mathrm{~h}$ at $37^{\circ} \mathrm{C}$. After reacting with DAB reagent for several seconds, the sections stained with hematoxylin for $3 \mathrm{~min}$, and observed in the microscope. For immunofluorescent analysis, all procedures were same as IHC analysis expect to endogenous peroxidase activity blocking. The substantia nigra tissue sections were incubated primary antibody of glial fibrillary acidic protein (GFAP, 1:200, Proteintech Technology, China) at $4^{\circ}$ Covernight, and then an Alexa Fluor 594 affinipure goat anti-rabbit IgG secondary antibody (Merck Technology, USA) for $0.5 \mathrm{~h}$ at room temperature. The images were acquired by the AV300-ASW confocal microscope (Olympus America Inc., Center Valley, USA). For blank control group, the primary antibody was replaced by PBS, and other incubation steps were same.

\section{Open Field Activity (OFA) Test}

OFA monitoring was a powerful assessment tool that quantifies distance traveled and stereotypic movements within the defined space of the Open Field Arena. Briefly, before the open-field test, $75 \%$ ethanol was used to clean the test area. After the smell was removed, each mouse was placed in the middle of open field test area $(81 \mathrm{~cm} \times 81$ $\mathrm{cm} \times 40 \mathrm{~cm}$ ) for testing. The open field test area was divided into two zone settings, both the central zone1 $(8 \times 8$ grid $)$ and the overall Zone2 $(16 \times 16$ grid $)$. The video was recorded for $3 \mathrm{~h}$ to record the movement track of the mice.

\section{Detection of antioxidant enzymes.}

Measurement of Total protein content. The total protein content of SNR and $\mathrm{CPu}$ tissue were measured using a protein Assay Kit (Nan Jing Jian Cheng Bioengineer 
Institute). The total protein content was detected using bovine serum albumin as a standard. The protein content was expressed as gprot/L of tissue.

Measurement of GSH-PX and T-AOC activity. According to the appropriate kit protocol, the levels of the glutathione peroxidase (GPx) and total antioxidant capacity (T-AOC) were measured in the SNR and CPu tissue. Test kits were purchased from the NanJing Jian Cheng Bioengineering Institute (Nanjing, China). The GSH-PX activity and T-AOC activity were expressed as U/mgprot of tissue.

Table S1. The ICP-AES results of $\mathrm{Yb} / \mathrm{Er} / \mathrm{CeO}_{2-\mathrm{x}}$ upconversion nanoparticles

\begin{tabular}{cccccc}
\hline Theoretical & Sampling & Measured & Instrument & Content & Mole percentage \\
value $(\mathrm{mol} \%)$ & quality $(\mathrm{g})$ & element & reading & $(\mathrm{mg} / \mathrm{kg})$ & \\
& & & $(\mathrm{mg} / \mathrm{L})$ & \\
& & & & \\
\hline $1(\mathrm{Er})$ & 0.0632 & $\mathrm{Er}$ & 0.2153 & 8515.8 & 0.88 \\
$1(\mathrm{Yb})$ & 0.0599 & $\mathrm{Yb}$ & 0.2121 & 8852.3 & 0.90 \\
$3(\mathrm{Yb})$ & 0.0654 & $\mathrm{Yb}$ & 0.7111 & 27182.5 & 2.80 \\
$5(\mathrm{Yb})$ & 0.0579 & $\mathrm{Yb}$ & 1.2903 & 55712.9 & 5.73 \\
$7(\mathrm{Yb})$ & 0.0753 & $\mathrm{Yb}$ & 2.0565 & 68277.6 & 7.02 \\
$9(\mathrm{Yb})$ & 0.0794 & $\mathrm{Yb}$ & 2.8734 & 90472 & 9.31 \\
\hline
\end{tabular}




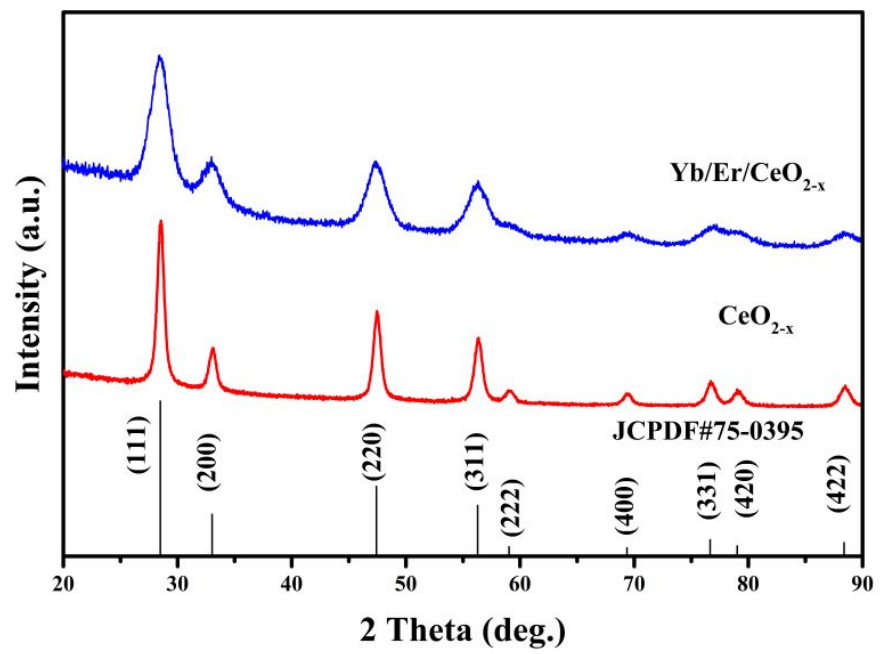

Figure S1. The x-ray diffraction of pure $\mathrm{CeO}_{2-\mathrm{x}}$ and $\mathrm{Yb} / \mathrm{Er} / \mathrm{CeO}_{2-\mathrm{x}}$ upconversion nanoparticles

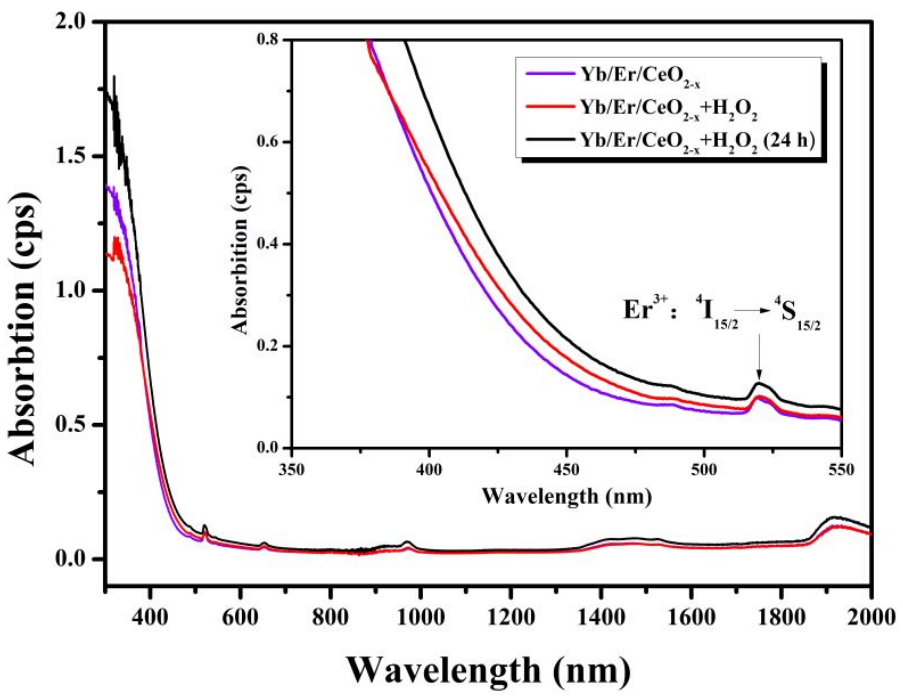

Figure S2. The UV/Vis absorption curves of $\mathrm{Yb} / \mathrm{Er} / \mathrm{CeO}_{2-\mathrm{x}}, \mathrm{Yb} / \mathrm{Er} / \mathrm{CeO}_{2-\mathrm{x}}$ with $\mathrm{H}_{2} \mathrm{O}_{2}$ and $\mathrm{Yb} / \mathrm{Er} / \mathrm{CeO}_{2-\mathrm{x}}$ with $\mathrm{H}_{2} \mathrm{O}_{2}$ after 24 hours. 


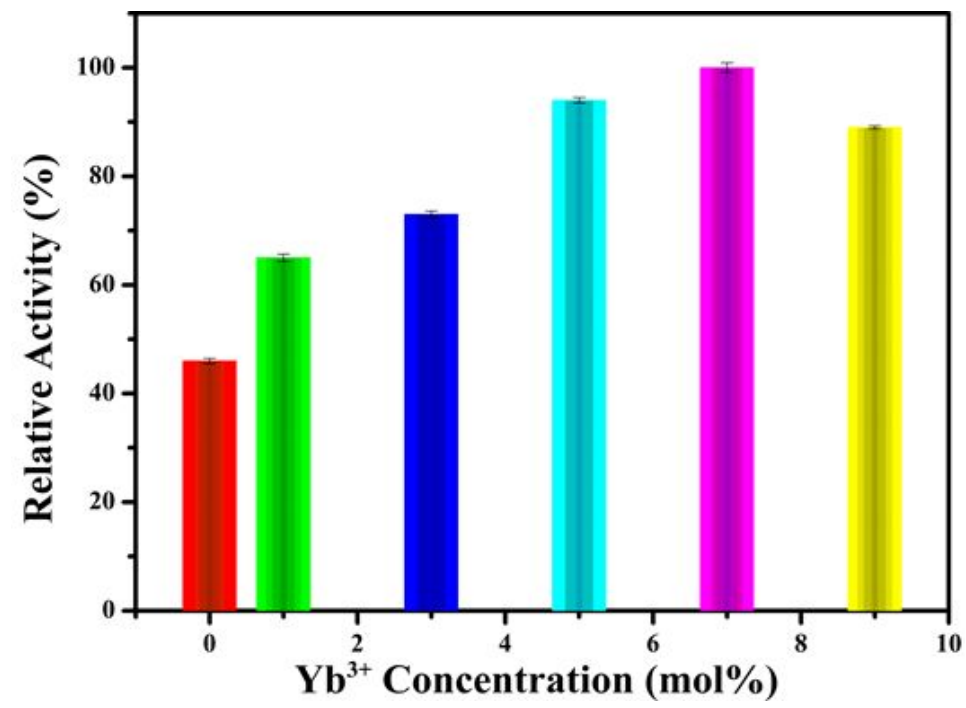

Figure S3. Relative catalytic activity of $\mathrm{Yb} / \mathrm{Er} / \mathrm{CeO}_{2-\mathrm{x}}$ with different $\mathrm{Yb}^{3+}$ concentrations $(0$ mol\%, $1 \mathrm{~mol} \%, 3 \mathrm{~mol} \%, 5 \mathrm{~mol} \%, 7 \mathrm{~mol} \%$ and $9 \mathrm{~mol} \%)$.

TMB due to its high sensitivity and stability was a good catalytic substrate. TMB was selected as the substrate to investigate the catalytic activity of pure $\mathrm{CeO}_{2-\mathrm{x}}$ and $\mathrm{Yb} / \mathrm{Er} / \mathrm{CeO}_{2-\mathrm{x}}$. The activity of $\mathrm{Yb} / \mathrm{Er} / \mathrm{CeO}_{2-\mathrm{x}}(\mathrm{Yb} 7 \mathrm{~mol} \%$, Er $1 \mathrm{~mol} \%$ ) was recorded as $100 \%$.

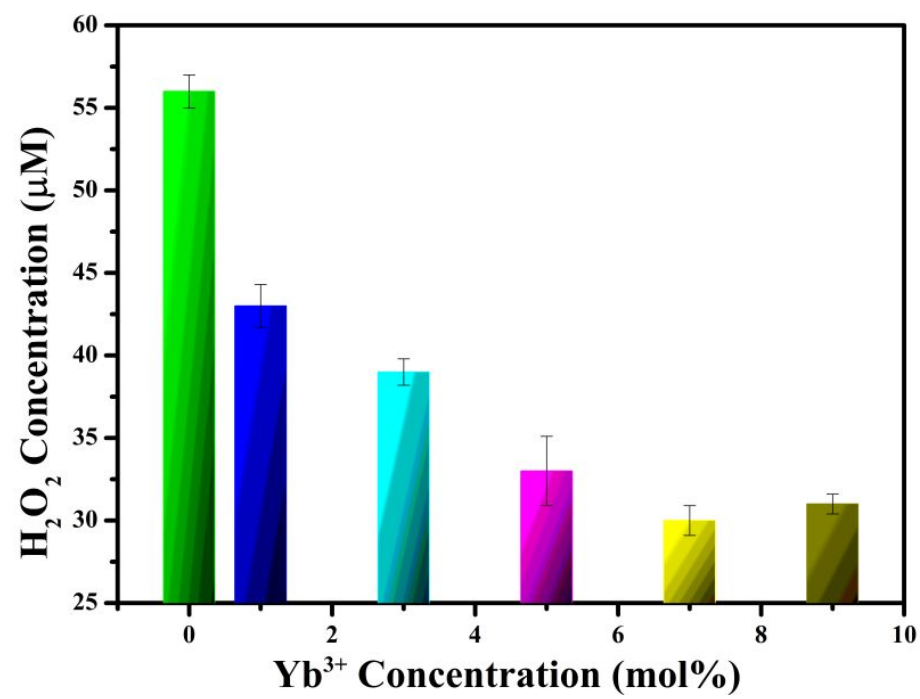

Figure S4. Scavenging activitiy of $\mathrm{H}_{2} \mathrm{O}_{2}$ by $\mathrm{Yb} / \mathrm{Er} / \mathrm{CeO}_{2-\mathrm{x}}$ with different $\mathrm{Yb}^{3+}$ concentrations (0 mol\%, $1 \mathrm{~mol} \%, 3 \mathrm{~mol} \%, 5 \mathrm{~mol} \%, 7 \mathrm{~mol} \%$ and $9 \mathrm{~mol} \%$ ). 


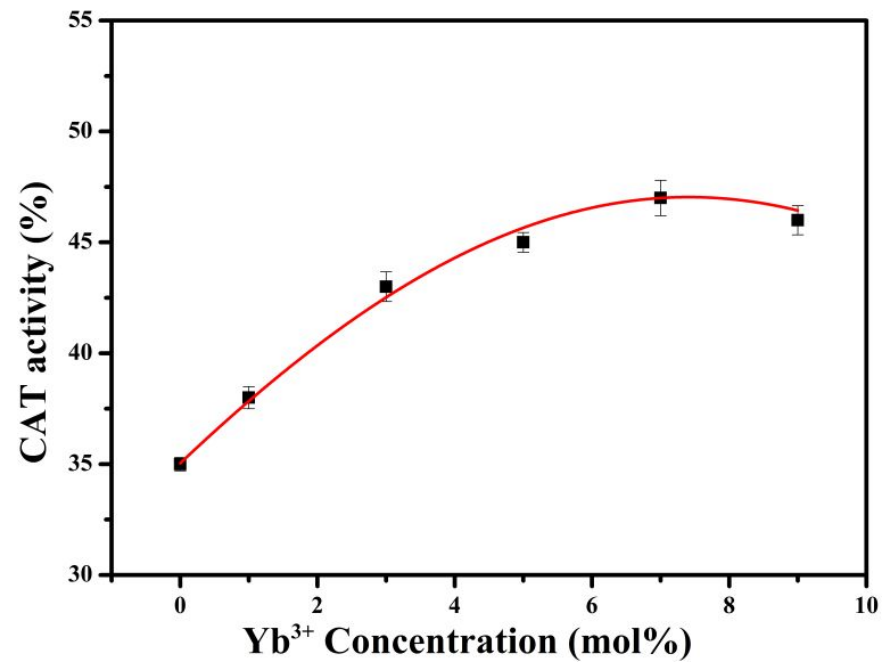

Figure S5. CAT-like activity of $\mathrm{Yb} / \mathrm{Er} / \mathrm{CeO}_{2-\mathrm{x}}$ with different $\mathrm{Yb}^{3+}$ doping concentrations.

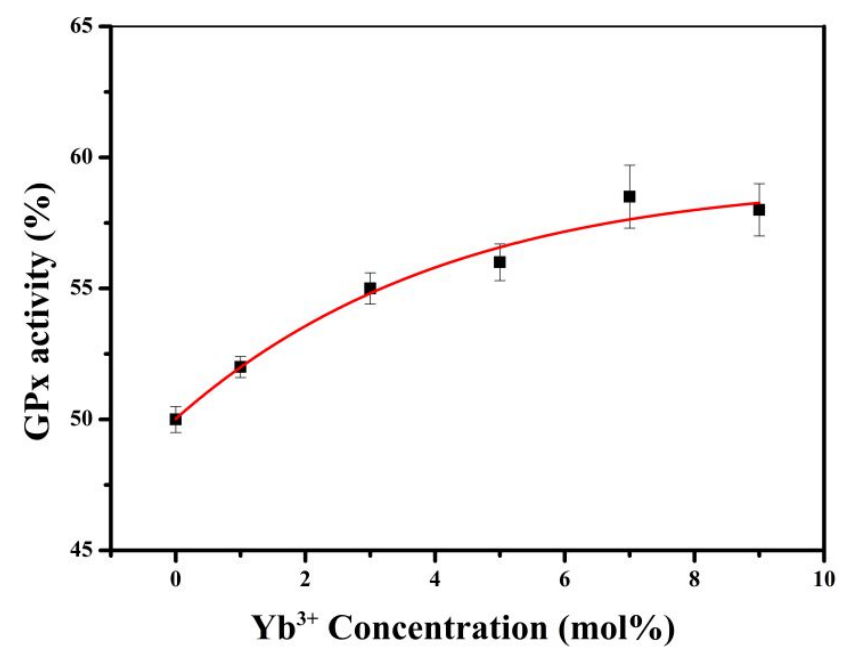

Figure S6. GPx-like activity of $\mathrm{Yb} / \mathrm{Er} / \mathrm{CeO}_{2-\mathrm{x}}$ with different $\mathrm{Yb}^{3+}$ doping concentrations. 